\title{
The quarantine experience set off by the COVID-19 pandemic, seen from a phenomenological perspective
}

\section{A experiência da quarentena promovida pela pandemia da Covid-19 segundo uma perspectiva fenomenológica}

Willian Isao Miyamoto ${ }^{1}$, Flávio Guimarães-Fernandes ${ }^{2}$, Daniela Ceron-Litvoc ${ }^{3}$

${ }^{1}$ Psiquiatra pelo Instituto de Psiquiatria do HCFMUSP. Membro da Sociedade Brasileira de Psicopatologia Fenômeno-Estrutural. E-mail: wi.miyamoto@gmail.com.

${ }^{2}$ Médico Psiquiatra da Sociedade Brasileira de Psicopatologia Fenômeno- Estrutural. Docente do Curso de Especialização em Psicopatologia Fenomenológica da Faculdade de Ciências Médicas da Santa Casa de São Paulo. Pesquisador em Estudos Qualitativos pela Universidade de São Paulo. E-mail: fernandesfg95@gmail.com.

${ }^{3}$ Psiquiatra. Presidente da Sociedade Brasileira de Psicopatologia Fenômeno- Estrutural. Docente do Curso de Especialização em Psicopatologia Fenomenológica da Faculdade de Ciências Médicas da Santa Casa de São Paulo. Pesquisadora em Estudos Qualitativos pela Universidade de São Paulo. Email: daniela@ ceronlitvoc.com. 


\begin{abstract}
The pandemic caused by the COVID-19 virus has imposed changes to daily life in every social sphere. The ways in which we interact with each other have had to be reviewed, questioned, and readapted. The term "catastrophe" seems to be adequate to define this historical event, given the drastic, tragic changes experienced in every sphere of society, and particularly evident in daily events and interpersonal relationships. In defining the daily changes brought about by the quarantine situation as a catastrophic situation, we will focus on the shocks to be undergone by the structures of consciousness in their intention toward the world and, from a protentive possibility, their reconstruction after the crisis. For this analysis, the article has been split into five parts: definition of the concept of limit situation, as per Jaspers, with subsequent analysis of two limit situations experienced by individuals in quarantine; suspension of values and correlation between the temporal experience lived during this period and the concept of expectation, as per Minkowski; analysis of this experience, drawing on Blankenburg's description of "loss of natural evidence"; possibilities of psychic reaction to this catastrophic event; and, finally, how phenomenological therapy can help individuals affected by this situation.
\end{abstract}




\section{Resumo}

A pandemia da Covid-19 causada pelo novo coronavírus impôs mudanças na vida cotidiana em todas as esferas sociais. As formas como interagimos uns com os outros tiveram que ser revistas, questionadas e readaptadas. Nesse contexto, o termo "catástrofe" parece adequado para definir este acontecimento histórico, dadas as mudanças drásticas e trágicas vividas em todas as esferas da sociedade, e particularmente evidentes nos acontecimentos diários e nas relações interpessoais. Ao definir as mudanças cotidianas ocasionadas pela situação de quarentena como uma situação catastrófica, enfocaremos os choques sofridos pelas estruturas de consciência em sua intenção de relação com o mundo e, a partir de uma possibilidade protentiva, sua reconstrução após a crise. Para esta análise, o artigo foi dividido em cinco partes: definição do conceito de situação-limite, segundo Jaspers, com posterior análise de duas situações-limite vividas por indivíduos em quarentena; suspensão de valores e correlação entre a experiência temporal vivida nesse período e o conceito de expectativa, conforme Minkowski; análise desta experiência, com base na descrição de Blankenburg de "perda de evidência natural"; possibilidades de reação psíquica a este evento catastrófico; e, por fim, como a terapia fenomenológica pode ajudar os indivíduos afetados por essa situação. 


\section{Introduction}

The pandemic caused by the COVID-19 virus has imposed changes to daily life in every social sphere. The ways in which we interact with each other, go about our business, daily routines, and supplying provisions, among a myriad of other activities, have had to be reviewed, questioned, and readapted. Even everyday objects, or the very air we breathe, now raise concerns: Are they contaminated? Has someone just spread their virus-laden droplets there? In Brazil, for instance, a mask-wearing passerby would have made for an outlandish sight prior to February 2020. Only post-transplant patients or individuals otherwise undergoing immunosuppression would be expected to don such conspicuous protective gear in public. Today, with the pandemic in full swing, and the alarming proportions it has reached in Brazil, wearing a mask in the street has become the norm, not only in terms of rules imposed, but also as a culturally assimilated reaction-a direct consequence of a new reality shaped by the arrival of a novel coronavirus.

In trying to define this historical event, the term "catastrophe" springs to mind, given the drastic, tragic changes experienced in every sphere of society, and particularly evident in daily events and interpersonal relationships.

“Catastrophe" is a word with Greek roots-kata, 'down,' and strephein, 'twist, turn'conveying the idea of overturning, of sudden end (Etymonline, 2020), "a very serious event affecting human lives," and "an event, generally of natural causes and great proportions, that causes death and destruction" (da Silveira Bueno, 1974). The present article will also address the developing aftermath implied by the term-i.e., the paths unfurling after a tragic event. In Greek tragedies, catastrophe is the act wherein the narrative takes a sudden turn, casting the protagonist into a situation of imminent risk - a juncture at which everything is destroyed and the lead character must find a way out of the crisis. The narrative course then turns to the character's possibilities of action arising from the tragic event: the catastrophic situation expands beyond the rupture line, to encompass the expectation of subsequent reconstruction (dos Santos, 2005). ${ }^{4}$

\footnotetext{
${ }^{4}$ The classical work Oedipus illustrates the role of tragedy in theater and subsequent interest in the possibilities of reaction by the central character, "who finds himself the victim of a sudden change imposed by fate. A terrible event precipitates his fall into disgrace and stifles his joys, hurling him into the world of shadows. Everything collapses around him. In fact, his qualities are what render him capable of acting and reacting in the face of suffering. The hero of a tragic work of art not only shows extraordinary nobility in his manner of bearing his vicissitudes, but also demonstrates dignity amid his fall. He obstinately stands unwavering even in an untenable, impossible situation. He does not retreat in the face of his own ruin, as if his designs and aspirations mattered more to him than life itself" (dos Santos, 2005).
} 
Dealing with the concepts of rupture and reconstruction sets our thinking to a temporal thread. Given that existence is pre-reflexively founded on a temporal, intersubjective basis, events of great impact on human existential possibilities can be analyzed taking these foundations as a departure point. In defining the daily changes brought about by the pandemic (the quarantine situation) as a catastrophic situation, we will focus on the shocks to be undergone by the structures of consciousness in their intention toward the world and, from a protentive possibility, their reconstruction after the crisis. For this analysis, the article has been split into five parts: definition of the concept of limit situation, as per Jaspers, with subsequent analysis of two limit situations experienced by individuals in quarantine; suspension of values during the quarantine and correlation between the temporal experience lived during this period and the concept of expectation, as per Minkowski; analysis of this experience, drawing on Blankenburg's description of "loss of natural evidence"; possibilities of psychic reaction to this catastrophic event; and, finally, how phenomenological therapy can help individuals affected by this situation.

\section{Limit situation}

From an existential point of view, the metaphor of Greek catastrophe can be accurately exemplified based on Jasper's concept of limit situation. This concept is based on the idea of basic situations (Grundsituationen), ${ }^{5}$ characteristic of human existence: its contradictions (antinomies) and finitude. Jaspers posits that the precondition (ontology) of experiencing limit situations is the fundamental antinomic structure of existence - the experience that existence is determined by a continuous movement between contradictions. In daily life, these basic situations, or antinomies, remain in the background, but may surface in situations that hint at a catastrophe, turning what had previously been experienced as plain generality into distressing suffering for the individual: these are limit situations (Fuchs, 2013).

Antinomies made manifest by limit situations have a revelatory nature, pointing to what Jaspers calls a "housing" (Gehäuse): ${ }^{6}$ a consolidated structure of core thoughts, values, and

\footnotetext{
${ }^{5}$ What we have translated as "basic situation" is similar in meaning to the German Grundsituationen. To this end, we have drawn on the concept of basis, a term originating from Latin basis, 'foundations' (of a building). A basic situation is therefore one which the individual anchors himself to or takes root on (da Silveira Bueno, 1974).

6 The word has been rendered in Portuguese as envoltório, a term that impoverishes the idea of Gehäuse. Envoltório (literally 'a wrapping') connotes cover, protection, anything that serves to involve, wrap, shield (de Silveira Bueno, 1974), whereas the idea of house (Haus) evokes what is comfortable, cozy, as familiar as home.
} 
attitudes that provide boundaries of protection and safety against existential angst, giving meaning to the world and rendering it understandable (Fuchs, 2013).

This article describes two situations experienced during the pandemic - the first of a temporal nature; the second of an intersubjective nature-which are related to an increased incidence of psychic suffering (Luo, 2020; McGinty, 2020; Wang, 2020; Shi, 2020) observed in the quarantine situation. This epidemiological observation can be correlated with the fact that the limit situation imposed by the quarantine predisposes to a rupture in this housing.

a) Experiencing a suspension of values during quarantine

The first limit experience to be reported here concerns an intersubjective aspect that has come to the fore, making explicit the catastrophe previously described. In his book Psychology of World Conceptions, and more specifically in the third chapter, "The Life of Spirit", Jaspers introduces his argumentation on limit situations drawing on the understanding that the forces of human life are shaped from values. In addition to this, values obey some sort of hierarchy in human experience.

Faced with the threat posed by COVID-19, societies have, quite consistently, prioritized the pursuit of one value over all others: the avoidance of death. We will not engage in the philosophical discussion on the dialectic involved in the primacy assigned to this social-medicalpolitical value in the context of the pandemic, as it is outside the scope of this article, but the input of Italian philosopher Giorgio Agamben (2020) on this issue will be considered. What seems evident, however, is that the worldwide adherence to this value above all others has led all societies to assigning primordial importance to the implementation of quarantines. This said, the event here denoted as a catastrophe does not directly concern the virus, or even death, but rather a reaction consequent to prioritizing the avoidance of death at the expense of other values, bringing about a reconfiguration of the values held in previous basic social frameworks. This reconfiguration paves the way for the said catastrophe.

In an article, published in The Lancet, Havi Carel aptly describes this picture:

With social distancing in many countries, much of this background structure has changed; norms of interaction that were once taken as given are gone. At times, there is a sense of not knowing what to do anymore, how to interpret and interact with other people. The rulebook is not only new; but also it is strangely incomplete. There are experiences of 
anxious uncertainty and of absence and loss, as our habitual patterns of expectation are repeatedly challenged by socially distanced public spaces. (Carel, 2020, p. 2)

Under these circumstances, there occurs what Carel terms "global uncertainty": "the loss of a once prereflective trust or confidence relating to most things in our lives" A number of elements of the pandemic experience are tinted by suspicion, uncertainty, and doubt. We mistrust the very air we breathe, the surfaces we touch. The most ordinary bodily events, such as a cough or sore throat, are cause for concern. Ultimately, this loss of ordinariness in everyday life leads to "a pervasive breakdown of habits. [...] The loss of norms, routines, and structure alters our sense of temporal passage. Some people report that time feels like an undifferentiated flow, an experience that is disorienting and dispiriting" (Carel, 2020. p. 2).

These values, argues Jaspers (1967), underpin our daily experiences and are where man draws his support, and without which the existential ballast is shaken. However, the philosopher adds that man rarely experiences feelings of despair when the structures providing support and ballast are shaken, because even when faced with situations where values are being challenged, these situations are experienced as casual, avoidable, surmountable, owing to their finite nature. In most situations, therefore, limit experiences have a positive facet: although our existential premise is being shaken, the world follows a pattern of familiarity and the "I," being protentive (Messas, 2012), is invited, out of existential angst, to re-experience itself in a new housing (Jaspers 1967; Fuchs 2013). The quarantine experience, however, fails to provide a glimpse of this finitude, given the significant disproportion between what Minkowski has termed "activity" and "expectation", to be addressed later on.

The limit situation thus becomes evident. Loss of everyday life, which is no other than loss of value certainties that previously provided a safe backdrop to our lives, as enveloping as a housing, becomes suddenly patent. The experience here is one of suspension of ontological certainties that used to give us support. Our values are put to the test: a gesture of approach from a friend is now construed as repulsive. This limit situation causes an epoché of daily habits and values, and this imposed reduction directly interferes with the "quality and nature of our experience of time. Time is disproportionately lengthened or shortened as the day unfolds" (Naudin, 2020, p. 113). This moment of uncertainty (suspension of values) then leads to a disproportion, whereby the basic antinomical structure leaves its backdrop (that which exists constitutes us in the essence of our being, but is not in our consciousness) and begins to inhabit the foreground (Fuchs, 2013). 
This experience is exemplified in an article by Professor Jean Naudin (2020) where he describes, in phenomenological terms, his personal experience of ambivalence in feeling equal measures of gratitude and guilt for working during the quarantine - as in the dream reported by A., one of our patients:

I was walking down the street amidst a crowd who looked at me vexatiously. Their stares became more glaring and disparaging as the dream unfolded. Everyone around me was wearing a mask and this perception led me to realize I wasn't. I sped up, as I was nearing home. Nonetheless, I was overtaken by a terrible feeling of anguish and embarrassment that consumed me, devitalized me. Upon waking, I felt overwhelming guilt in the form of selfunforgiveness in the face of my blunder. Shame at, unbelongingness to, and exclusion from people around me was the prevailing experience.

This account exemplifies the experiences triggered by a foreground manifestation of the basic antinomical structure.

Let's now proceed to the next argument, which addresses another anthropological disproportion experienced in the quarantine. Our approach will move out of the interpersonal constitution of consciousness to explore how the quarantine has impacted the experience of temporality.

b) Changes in temporality experienced during the quarantine: expectation

The loss of Gehäuse can also be addressed with a focus on temporality. Concepts developed by Eugène Minkowski will be employed to shed light on the experiences that can be had by consciousness in this perspective.

Minkowski, one of the first psychiatrists to employ phenomenology concepts to clarify modes of psychic illness, postulates in his oeuvre, influenced by philosopher Henri Bergson, that the psychic structure, healthy or otherwise, rests on a spatiotemporal framework, and that time and space are lived in an aprioristic-i.e., pre-reflexive-manner. From the concept of becominginextricable as it is from time, 'that 'fluid mass,' that shifting, mysterious, imposing, and mighty ocean that I see everywhere around me," which, however, "I admit, in saying that time unfolds, that it passes, that it flees in an irretrievable manner," although "it also advances, it progresses, it goes toward an indefinite and intangible future" (Minkowski, 2019, p.18) — and the concept of vital élan-which "gives a direction to life, constitutes [...] its most essential element," (2019, pp. 4445) the basis that enables us to act, whether failing or succeeding, Minkowski claims that the 
healthy psychic structure "is essentially oriented toward the future" (2019, p.80). According to him, "we look at the future and we see it in a broad and majestic perspective [...]. It makes of the future a reservoir of eternal and inexhaustible forces without which we could not continue to live" (2019, p.81).

Drawing on these ideas, Minkowski highlights six phenomena that constitute the foundations of lived future: activity and expectation; desire and hope; prayer and the ethical act. Detailing each of these phenomena is beyond the scope of this article, but to analyze the current situation we shall concentrate on the phenomena of activity and expectation, which, in a dialectic manner, dialogue and intertwine in the healthy structure of human consciousness. From this initial analysis, we shall demonstrate how the experience of quarantine disproportionately affects these phenomena, in favor of expectation.

Minkowski defines activity as "a global manifestation of the living being. It cannot be reduced to a multitude of different actions, each directed toward a precise end. Rather, it forms the base common to all actions, linking them together. It is an essential phenomenon of life. All that lives is active, and all that is active lives" (2019, p.83). Minkowski thus highlights the idea that the phenomenon of activity reveals itself by its very leaning toward and acting toward something. Activity would thus be the condition of possibility for our capacity to move toward a lived future. The notion that activity is a temporal phenomenon is what allows us to move toward the future and create it. It is also what imparts us the notion of immediate future, a future with diverse possibilities, albeit limited in number and quality by the immediate relationship of the individual with the world within the conditions of possibility ${ }^{7}$ and by the milieu, in its presentations and meanings. It is, therefore, from its intentional relationship with the world that we can think of the being in activity, projecting itself toward a future with the possibilities it has been given.

Minkowski posits that the vital phenomenon dialectically opposite to activity is expectation, not in the sense of waiting for a specific event (as with "a train that should pass by in a half-hour"), but something "much more elementary," which "englobes the whole living being, suspends his activity, and fixes him [...]. It contains a factor of brutal arrest and renders the individual breathless. One might say that the whole of becoming concentrated outside of the

\footnotetext{
${ }^{7}$ In Minkowski's words, "neither success nor failure modifies anything in the phenomenon of my activity in its primary form. they would not change its essential characteristics, which [...] form the very basis of our experiences relative to what we are able to do and to accomplish" (p. 86).
} 
individual swoops down on him in a powerful and hostile mass, attempting to annihilate him" (2019, p.87-88). Unlike activity (in which we lean toward the future), expectation involves suspension of our own activity: the future comes to us.

The quarantine has promoted radical changes to the experience of the world, for every individual. To think of the pandemic as a catastrophe is to embrace the idea that, although reality is unceasingly changing, there has been, during the current transformation, a rupture of such intensity that it has given rise to a new reality. In this new reality, plans are temporarily suspended, encounters with friends and family canceled, commitments deferred - with no foreseeable end to this suspension. In more general terms, activity as a phenomenon is restricted to the immediate future, thus turning expectation into the preponderant phenomenon.

In expectation, time is lived in the opposite direction: the future moves toward us, while in activity we are the ones heading toward the future. In the current expectation, however, there is no lived time. Temporal organization is fragmented - and, for Minkowski, "it would be false to say that in expectation I live the present and the immediate future, each linked to the other. In reality I live only the future, which, as such, tends to become present" (2019, p.89). It can be said that, during quarantine, there is an imbalance tipping toward expectation. The future where measures of isolation will be no longer needed, where encounters can take place without major concerns, and day-to-day activities can be ultimately resumed is not "at hand"-it is a future we cannot pursue. We find ourselves frozen in a present that defies updating, one that relates to a future that has lost its historical meaning.

In the structure of healthy human consciousness dwells a drive for self-renewal, for selfreconfiguration and (re)creation of new possibilities. In the current scenario, glimpses of reconfiguration have become unlikely, given the lack of an open future which we can refer to. We can only remain in expectation of transformations that are still underway. As in a catastrophe, it is not possible, from the present, to know beforehand the possible outcomes for the crisis (economic, social, political) we are steeped in. The current impossibility of "taking control" of a post-pandemic future, in the sense of acting toward the transformation of this future from our present, stalls us in successive moments that preclude a fluid timeline. 


\section{Quarantine and loss of natural evidence}

Based on the preceding analysis, let's now discuss the impact of the catastrophe situation on one's familiarity with the world, drawing on a concept developed by Wolfgang Blankenburg: "loss of natural evidence.".

Natural evidence is the indistinguishable ground on which habitual daily consciousness rests. It constitutes the support for and basis of the everydayness of human being-in-the-world. It has therefore a character of backdrop and at the same time of foundation (Blankenburg, 2013). The experience of natural evidence arises from one's relationship with the world: with temporality, with the constitution of the "I," and with intersubjective construction. As regards the situation addressed in this article, our interest lies in describing changes that affect both temporality and the intersubjective possibility of sharing stable values. As a historical event that has altered the "rules of the game," the pandemic has directly impacted the possibility of tacit recognition of shared rules of being-in-the-world. From a phenomenological perspective, these "rules of the game" or "conceptual generalities", are no more than relationships of respectiveness and reference (as per Heidegger), within which existence (Dasein) operates in situations that, strictly speaking, have just become a situation - although based on meanings that determine a respective being-in-the-world, they are not just any meanings, projected $a d$ hoc, but historically developed meanings to which the being-in-the-world is anchored (Blankenburg, 2013).

To conceptualize natural evidence, Blankenburg turns to the descriptions of world experiences by his patient Anna, who said that each of us should be aware of our own behavior, have our own path, way of thinking - our actions, humanity, sociability, all these rules of the game that one follows.

Our analysis is that, in the present historical moment, the shared experience has promoted a suspension of this implicit natural path. Life meanings are no longer natural; values previously viewed as stable have been modified.

This generalized shift is evidenced, for instance, when we find ourselves distrusting everything and everyone as potential sources of contamination, causing gestures of approach and affection to lose their long-held meaning and be perceived instead as threatening, or when we begin 
to question ourselves about bodily experiences that never raised an eyebrow before, but are now perceived as signs of a potentially fatal illness. ${ }^{8}$

The relationships of distance and proximity that make up the natural balance of intersubjective rapports have been severely disrupted and I am beginning to understand, by experiencing this disturbance at close hand, how much the constitution of the present time - what we may rather pompously term its transcendental functionis intertwined with that of others. When we can neither see faces while talking nor touch or be touched by others, the world is at risk of disembodying, the very flesh of the world denaturing itself, time hollowing itself out beyond measure. (Naudin, 2020, p. 113)

Human existence is anchored in the axioms of the everyday world, which underlie the system of evidence within which we move. They rescue what has always been forgotten in its banality, and only when they disappear do they emerge in their vital sense, which sustains and guarantees the normality of healthy everydayness. In the following analysis, it should be underscored that loss of natural evidence, as a moment or state in the development of existence, represents an imbalance, not necessarily pathological, between evidence and non-evidence (Blankenburg, 2013).

Blankenburg addresses the experience of loss of natural evidence reporting on the experiences of his patient Ana, whom he describes as schizophrenic. In schizophrenia, a constitutive change of temporality is observed, a disintegration of lived time (Fuchs, 2013). We can then consider that this form of being-in-the-world has "lost" its protentive capacity and is thus deprived of its anchoring in the world. In the experience reported in this article, by contrast, this "loss" of evidence is only temporary, albeit prolonged, and individuals have the possibility of reestablishing the dynamic proportion between evidence and non-evidence, owing to the protentive character of existence.

\section{Possibilities of psychic reaction triggered by a catastrophe}

The imbalance between evidence and non-evidence caused by the current limit situation calls for an analysis of individual protentive powers. Invited to a new experience of balance,

\footnotetext{
${ }^{8}$ Adding to the suspension of familiar ways of reacting and relating to the world, a further point merits emphasizing: the impact of the unknown. We find ourselves facing a new disease with multiple symptomatic presentations, without a clear shared experience of what it actually is.
} 
individuals open up to uncertainty. Faced with the need for new structural configurations, they will have two possible paths to follow: (a) reconstruction of the Gehäuse, with consequent reconfiguration of the dialectic operating between evidence and non-evidence, or $(b)$ a state of conserved imbalance, rupturing the harmonic constitution of existence - a state synonymous with psychic illness. Ontological understanding of reaction vectors requires analysis of existential vulnerabilities, the manner whereby these are exposed by the limit situation. These factors will promote reconfigurations in each individual structure, ultimately either determining a vector for expansion (resignification) or leading to paralysis (illness). Amid a catastrophe we can re-create ourselves, design a better version of ourselves_-just as we can succumb existentially.

What tragedy is needed to cause illness? As an initial definition, a traumatic event can be said to refer to any situation that sparks intense fear, helplessness, horror, and which resists appropriation, symbolization, and integration into a meaningful context (Fuchs, 2013) — any event that triggers the experience of imminent structural fracture, throwing us into an experience of dread. As López-Ibor (1942, p. 56) puts it, “it doesn't matter that the threat is objectively certain; it is enough that it appears as such"-i.e., the relevant point is not the isolated fact per se, but the intensity of the reaction and the structural impact it triggers in the individual.

Analyzing this situation therefore requires contemplating the individual structure and its possibilities of reacting to a tension. In a structural perspective, the pre-reflective constitutional characteristics, in their intentionality of consciousness, determine the points of vulnerability that will outline the possibilities of reaction: either healthy restructuring or structural deconfiguration. Each structure is unique in its vulnerabilities; each individual resonates to the movement of change in a particular manner. Some movements will shake our housing, leaving us vulnerable, to the point that the fractures thus created will lead to psychic illness, while in another structure the same movement will cause shaking but no fractures. "As important as the external history (the traumatic event) is to decipher the internal history, the experience" (López-Ibor, 1942, p. 103).

Naturally, a catastrophic situation carries in itself the power for chaos and imponderability, demanding more of individual structures, with heightened risk of illness. The central point, however, is not the concrete event, but the biographical structure and its possible intersections with the limit situation. Knowledge of the timeline (the biography) of an individual structure allows analysis of the whole of that structure. This totality is what guides the psychotherapeutic process, 
bringing to light the pre-reflexive characteristics that can promote movement and paralysis-i.e., those that need to be potentiated and those requiring care and support.

No event assimilated to one's history can ever be undone, because the biography is primarily supported on a continuous temporal basis (Blankenburg, 2018; Tamelini \& Messas, 2019). Some situations will promote ripplings more or less determinant to history, which may or not lead to trajectory deviations. Working with disproportions arising from a catastrophic event involves evaluating not only impacts, but also the capacity for synthesis following a structural jolt. Importantly, the synthesis that follows an experience is what enables the structure to preserve its primordial health component: proportion between parts (Blankenburg, 1982). We are therefore evaluating whether the shock sustained by the structure is a temporary paralysis or whether the impact has been so intense as to lead to psychic illness.

Mourning is a classical example of temporary paralysis. Despite all the mood shifts triggered, the individual maintains a certain control, a psychic autonomy relative to the reaction, such that the structural regions altered by bereavement (e.g., profound sadness tinting daily life activities) coexist in the psyche with healthy regions (maintenance of individual projects even when shaken by loss). Mourning involves an initial paralysis that will gradually be laid aside as the experience is reconfigured. New experiences will add new syntheses to psychic movements, affording the development of projects, losses notwithstanding.

In a temporary paralysis, reorganization will take place despite intense anguish: the structure's proportions are reharmonized and the potential for projecting expansion movements is maintained. Maintenance of the continuity line allows the psyche to recover, and the therapist's role will be one of both spectator and maintainer of possible structures capable of facilitating recovery - an unending process of psychic reorganization into a structure in which protension is a fundamental element.

However, the possibility of a reaction that exceeds healthy limits should not be overlooked. For Jaspers, these are experiential reactions intense enough to inhibit elaboration, or reactions that carry obscure, disturbing consequences (Jaspers, 1997). In this situation, psychic life is faced with an insurmountable impasse and, from then on, at least part of psychic life is immobilized, as with a previously expanding river delta that at a given point loses one of its ramifications. The ensuing impact on the structure as a whole will depend on the magnitude of this loss, but the design will 
never return to its original shape, irrevocably marked by a break. Part of the flow originally possible has been interrupted - the very concept of psychic fracture, of illness development. This is the idea that López-Ibor (1942, p.104) masterfully expresses: "Illness is a historical development that disrupts and disturbs the vital program to such a point that, during recovery, a new project installs itself in life history."

From the fracture - and the structural remodeling that ensues, with loss of the previous proportion between parts - existence is subjected to a new manner of experiencing the world. As previously defined, evidence of the world (one recognized as familiar) is an intersubjective, historically constructed action. Healthy psyche installs itself on a dialectic foundation that spans uninterrupted between the experience of evidence and non-evidence. Catastrophic situations, for the reasons expounded above, enhance the tension of vectors in this dialectic. In this perspective, a pathological event would occur when this relationship of tension is lost, deconfiguring a dialectic proportion. This, in turn, would promote the impossibility of experiencing tacit recognition of the world, determining what Blankenburg (2013, p.238) has termed "loss of natural evidence".

\section{Phenomenological therapy applied to moments of catastrophe}

The heuristic value of phenomenological thinking lies in the rich imbrication between an individual and the incarnate world (the world experienced by this existence). Unlike other approaches, which at times rely immoderately on historicity as causality, other times on endogeneity, this epistemological approach is capable of uniting both fronts into a suitable dialectic view. In this light, therapy involves evaluating both the situation and the being embodied in it.

By recognizing a pathology as something that threatens the vital flow and as a loss of proportionality between parts (Minkowski, 2019; Blankenburg, 1982), therapy builds on actions capable of promoting resumption of vital movement and structural rebalancing. Because relationships of proportion are not static, rebalancing a structure's constituent proportions requires planning on a temporal basis (Messas \& Tamelini, 2019). Phenomenological therapy affords an analysis of both psychotherapy and drug-therapy interventions. Both types of intervention are at the same level of importance, as long as prescribing them rests on identifying the psychopathological essence presenting before us. 
Drug therapy could be proposed both for temporary paralysis and psychic fracture, as an attempt to promote sufficient stability, albeit only exogenous, to entail a movement of reconfiguration. Pharmacology would thus be viewed not as a path precluding or enfeebling the psychotherapeutic process, but as a paved road that facilitates movement, and therefore the process of reconfiguration, of reconstruction of each individual by taking into account their anxieties and vulnerabilities.

Drug-associated or otherwise, the psychotherapeutic process can be described as an access to movement via interpersonality - the latter being the possibility of communion between structures by way of vital contact. The space generated from this contact widens individual experience, making a content more likely to mature and be assimilated to consciousness, with accommodation of its initial impact and reduction of fragmentations and distortions. In this process, the possibilities of movement available for a psyche shaken by a catastrophic situation are expanded. Interpersonal anchoring promotes stable conditions for movement, even on highly irregular terrain. The new synthesis - one that even carries in itself the scars of bitter mishaps-is what will enable the structure to resume its processes of balance between parts.

As a closing note, this would be the role of phenomenological therapy: as in Greek theater, to allow the main character to resume their trajectory after the catastrophe, acknowledging their own powers and vulnerabilities, as well as their essence, potentiating the possibility of creation and movement.

\section{Conclusion}

The new coronavirus pandemic has imposed major changes on daily life in every society. Faced with various ethical and moral dilemmas-including those concerning eligibility for intensive care amid the unfeasibility of guaranteeing it to entire populations - societies around the world have attempted to prevent deaths by implementing social isolation.

The quarantine process can be likened to a psychic catastrophe, with multitudes directly affected by it, as pointed out in a number of articles reporting increased rates of mental disorder. The catastrophic event described here shares two experiential aspects with Karl Jaspers' limit situations: a subversion of values and a disproportion of expectation relative to activity. 
Associated with the experience of presentification resulting from temporal inversion, the suspension of values that once held together a backdrop for our lives bears a parallel, in phenomenological terms, with Blankenburg's description of "loss of natural evidence." While these phenomena may be similar in these intersubjective and temporal aspects, at times leading to experiencing loss of reference relative to the "I," the vast majority of individuals have not lost their protentive constitution, as they might in the event of schizophrenia.

Individual structures will be reconfigured from the situations in which they are immersed and from individual potentialities, to the point of either defining a vector toward expansion (resignification) or leading to paralysis (illness). Phenomenological therapy can play a crucial role in helping these subjects resume their capacity for self-reorganizing and outlive this catastrophic moment with even more power and movement. 


\section{A experiência da quarentena promovida pela pandemia da Covid-19 segundo uma perspectiva fenomenológica}

\section{Introdução}

A pandemia da Covid-19 causada pelo novo coronavírus provocou alterações no cotidiano em todas as instâncias sociais. A partir desta situação, as formas como as pessoas interagem entre si, com o trabalho, com a rotina diária e com a provisão de suplementos para casa, entre outras, foram repensadas, questionadas e reformuladas. Até mesmo objetos do cotidiano ou o ar que se respira se transformaram em pontos de consideração: será que estão contaminados? Será que alguém acabou de espalhar gotículas contaminadas? No Brasil, por exemplo, até fevereiro de 2020 seria muito estranho encontrar uma pessoa usando máscara na rua. Esperava-se, culturalmente, que apenas pessoas que realizaram transplantes, ou que se submeteram a outras situações que promovessem imunossupressão, usassem tais acessórios de proteção. Hoje, após o início da pandemia de fato e das proporções assombrosas que tomou no Brasil, sair às ruas de máscara transformou-se em regra, não apenas do ponto de vista legal, mas uma reação culturalmente assimilada. Uma consequência direta da nova realidade provocada pelo surgimento do novo coronavírus.

Se observarmos as mudanças que essa situação causou na sociedade como um todo, percebe-se que este evento histórico pode ser definido como uma catástrofe, no sentido de que é uma situação de mudanças drásticas e trágicas da realidade que afeta todas as instâncias da sociedade, em especial os eventos cotidianos e as relações interpessoais.

"Catástrofe" é uma palavra de origem grega: de kata, para baixo e strophé, torção ou virada, dando uma ideia de reviravolta ou subversão (Etymonline, 2020), que define "1- um acontecimento muito grave, que afeta seriamente a vida das pessoas" e "2- Acontecimento, geralmente de causas naturais e de grandes proporções, que provoca mortes e destruição" (da Silveira Bueno, 1974). Porém, neste texto, discutiremos também o desdobramento temporal embutido no conceito da palavra, ou seja, os caminhos abertos após um evento trágico. Na tragédia do teatro grego, a catástrofe é o ato da peça em que ocorre uma virada súbita na narrativa que coloca o personagem principal em uma situação de risco iminente. Momento em que tudo é destruído para que o 
personagem principal possa reconstruir um desfecho a partir da crise. O rumo da narrativa se volta para as possibilidades de ação do personagem a partir do evento trágico, ou seja, a situação catastrófica se expande para além da ruptura, debruçando o olhar para a expectativa de reconstrução posterior (dos Santos, 2005) 9 .

Trabalhar com os conceitos de ruptura e reconstrução remete o pensamento para uma linha temporal. Como a existência é fundamentada pré-reflexivamente em uma base temporal e intersubjetiva, eventos de grande impacto nas possibilidades existenciais humanas podem ser analisados a partir desses fundamentos. Ou seja, ao definirmos as alterações cotidianas causadas pela pandemia (quarentena) como uma situação de catástrofe, estamos focando nosso olhar nos abalos que serão sofridos pelas estruturas da consciência em sua intenção de relação com o mundo e, a partir de uma possibilidade protentiva, as suas reconstruções após a crise. Para esta análise, dividiremos o texto em 5 partes: a definição do conceito de situação-limite segundo Jaspers e a posterior análise de duas dessas situações vividas pelos indivíduos na quarentena: a suspensão dos valores na quarentena e a correlação da experiência temporal vivida durante esse período ao conceito de espera definido por Minkowski; a análise dessa experiência a partir da descrição da "Perda da evidência natural" em Blankenburg; as possibilidades de reações psíquicas frente a esse evento catastrófico e, por fim, como a terapêutica fenomenológica pode ajudar os indivíduos afetados por essa situação.

\section{Situação-limite}

A metáfora da catástrofe grega pode ser exemplificada com acurácia do ponto de vista existencial a partir do conceito de situação-limite de Karl Jaspers. Tal conceito tem como pressuposto a ideia de situações básicas (Grundsituationen $)^{10}$ que são características da existência

\footnotetext{
${ }^{9}$ A obra clássica Édipo ilustra o papel da tragédia no teatro e o posterior olhar para as possibilidades de reação do personagem central: "De repente, vê-se vítima de uma alteração brusca imposta pelo destino. Um acontecimento terrível o conduz à desgraça e sufoca as suas alegrias, arremessando-o ao mundo das sombras. Tudo desaba ao seu redor. Com efeito, é graças às qualidades que o caracterizam que ele consegue agir e reagir face a tais sofrimentos. O herói de uma obra de arte trágica demonstra extraordinária nobreza na forma como os suporta e revela dignidade na queda. Obstinadamente, mantém-se firme mesmo quando se trata de uma posição insustentável ou impossível. Ele não recua perante a própria ruína, como se seus desígnios e aspirações lhe importassem mais que a própria vida." (dos Santos, 2005).

${ }^{10} \mathrm{O}$ que traduzimos aqui por situação básica tem significado similar ao Grundsituationen do alemão. Referimo-nos ao conceito de "base". Base vem do latim basis e significa fundamento, alicerce e, portanto, uma situação básica é aquela fundamental, na qual o indivíduo se ancora ou se enraíza (da Silveira Bueno, 1974).
} 
humana: suas contradições (antinomias) e sua finitude. Consequentemente, Jaspers postula que a pré-condição (ontologia) da experiência de situações-limite é a estrutura antinômica fundamental da existência, ou seja, a vivência de que a existência é determinada por um contínuo movimento entre contradições. No nosso cotidiano, essas situações básicas, ou antinomias, permanecem como pano de fundo em nossas vidas; no entanto, em situações que remetem à catástrofe, elas podem vir à tona e aquilo que antes era experienciado como simples generalidade torna-se sofrimento angustiante para o indivíduo: essas são as situações-limite (Fuchs, 2013).

Essa manifestação das antinomias, permitida pelas situações-limite, tem uma natureza reveladora que nos apresenta aquilo que Jaspers chama de "envoltório" (Gehäuse)" ${ }^{11}$ Tais envoltórios são estruturas consolidadas de pensamentos, valores e atitudes fundamentais que oferecem limites de proteção e segurança frente às angústias existenciais e, assim, esses envoltórios conferem significado e compreensibilidade ao mundo (Fuchs, 2013).

O que queremos descrever neste artigo são duas conjunturas experienciadas durante a pandemia, uma de característica temporal e a outra intersubjetiva, que se relacionam com o aumento da incidência de sofrimento psíquico (Luo, 2020; McGinty, 2020; Wang, 2020; Shi, 2020) observado na situação de quarentena. Esta observação epidemiológica pode ser correlacionada com o fato de que a situação-limite imposta pela quarentena predispõe à quebra desse envoltório.

a) Suspensão dos valores experimentada na quarentena

A primeira experiência-limite que iremos descrever diz respeito a um aspecto intersubjetivo que ganha relevo e explicita a catástrofe anteriormente enunciada. Em seu livro Psicologia das concepções de mundo, mais especificamente em seu capítulo terceiro "A vida do espírito", Karl Jaspers antecipa sua argumentação a respeito da situação-limite a partir do entendimento de que as forças da vida humana são dadas a partir dos valores. Mais do que isso, os valores obedecem a uma espécie de hierarquia na experiência humana.

A partir da ameaça trazida pela Covid-19, as sociedades, de maneira muito similar, priorizaram um valor como o valor a ser perseguido em detrimento dos outros: a evitação da morte. Por não ser escopo do artigo, passaremos ao largo da discussão filosófica a respeito da dialética

\footnotetext{
${ }^{11}$ A noção de envoltório é empobrecida em relação à de Gehäuse. Em língua portuguesa, envoltório significa capa, proteção, tudo o que serve para cobrir, envolver, proteger (da Silveira Bueno, 1974), porém a ideia de casa (Haus) traz um significado daquilo que é habitual, confortável, aconchegante, conhecido, familiar como a nossa moradia.
} 
incutida na escolha desse valor social-médico-político como o único a ser contemplado no contexto da pandemia, mas indicamos a colaboração do filósofo italiano Giorgio Agamben (2020) a respeito desse tema. O que nos parece evidente, contudo, é que a escolha desse valor mundo afora tornou primordial, para as sociedades, a realização da quarentena. Com isto, o evento aqui anunciado como catástrofe não diz respeito diretamente ao vírus, nem mesmo às mortes, mas sim a uma reação consequente à priorização de evitação da morte em detrimento de outros valores, provocando uma reconfiguração valorativa nas constituições básicas sociais anteriores. Tal reconfiguração propicia a catástrofe anteriormente anunciada.

Em artigo publicado na The Lancet, Havi Carel explicita muito bem o que estamos descrevendo:

Com o distanciamento social em muitos países, muito dessa estrutura de fundo mudou; as normas de interação que antes eram tidas como dadas se foram. Às vezes, há uma sensação de não saber mais o que fazer, como interpretar e interagir com outras pessoas. O livro de regras não é apenas novo, mas também estranhamente incompleto. Existem experiências de incerteza ansiosa e de ausência e perda, pois nossos padrões usuais de expectativa são repetidamente desafiados por espaços públicos socialmente distantes. (Carel, 2020, p.2)

O que ocorre, então, a partir disso, é o que a autora chama de incerteza global, ou seja, "a perda de uma confiança antes reflexiva ou relativa à maioria das coisas em nossas vidas". Assim, vários elementos da experiência pandêmica são caracterizados por suspeita, incerteza e dúvida. Duvidamos do ar que respiramos, das superfícies que tocamos. Ficamos incertos a respeito de eventos absolutamente corriqueiros corporais, como tossir ou uma sensação de garganta inflamada. Por fim, essa perda da cotidianidade leva a "um colapso generalizado de hábitos(...) A perda de normas, rotinas e estrutura altera nosso senso de passagem temporal. Algumas pessoas relatam que o tempo parece um fluxo indiferenciado, uma experiência desorientadora e desanimadora.". (Carel, 2020, p.2)

Esses valores que estão na base de nossas experiências usuais, argumenta Jaspers (1967, p.302), são "onde o homem tem seu apoio" e, sem eles, o lastro existencial é abalado. Porém, prossegue o filósofo, raras vezes o homem experimenta uma sensação de desespero diante do abalo das estruturas que oferecem apoio e lastro, pois mesmo diante de situações em que os valores nos colocam resistência, essas são vividas como "casuais, evitáveis e superáveis; já que possuem um caráter finito (...)". Portanto, na maior parte das situações, a experiência-limite possui um aspecto 
positivo, pois, a despeito de que há um estremecimento da nossa premissa existencial, o mundo segue um padrão de familiaridade e o "eu" é convidado, por ser protentivo, (Messas, 2012) a se reexperimentar em um novo envoltório a partir da angústia existencial (Jaspers, 1967; Fuchs, 2013). A experiência durante a quarentena, no entanto, não permite o vislumbre dessa finitude, visto que ocorre uma desproporção importante daquilo que Minkowski chamou de atividade e espera, que veremos a seguir.

Fica clara a situação-limite experienciada. A perda da cotidianidade, que nada mais é do que a perda das certezas valorativas que antes figuravam como um pano de fundo seguro de nossas vidas, como um envoltório, é sumariamente interrompida. Temos aqui uma vivência de suspensão das certezas ontológicas que nos davam sustentação. Nossos valores são colocados à prova, um gesto de aproximação de um amigo agora é experienciado como algo repulsivo. Essa situaçãolimite determina a realização de uma Epoché dos hábitos e valores cotidianos, e essa redução imposta interfere diretamente na "qualidade e [n]a própria natureza da experiência do tempo. Ele se estende ou se encurta desmesuradamente ao longo do dia." (Naudin, 2020, p.113). Esse momento de incerteza (suspensão de valores), então, ocasiona uma desproporção, em que a estrutura antinômica básica sai de seu plano de fundo (aquilo que existe nos constitui na essência do nosso ser, mas não está na nossa consciência) e passa a habitar o plano principal. (Fuchs, 2013)

Essa experiência pode ser exemplificada em artigo do prof. Jean Naudin (2020), no qual descreve fenomenologicamente a vivência pessoal de ambivalência ao sentir gratidão e culpa, na mesma medida, por trabalhar na quarentena. Assim como no relato do sonho da paciente A., de um dos autores a seguir:

Caminhava pela rua entre uma multidão de pessoas que me olhava de forma vexatória. Os olhares iam ficando mais intensos e depreciativos à medida que o sonho progredia. Todos à minha volta estavam de máscara e essa percepção me levou a realizar que eu estava sem. Apertei o passo pois estava próxima à minha casa. Mesmo assim era tomada por uma terrível sensação de angústia e constrangimento que me consumia, me desvitalizava. Quando acordei, senti uma culpa avassaladora sob a forma de inconformismo perante minha falta, predominavam as vivências de vergonha, despertencimento e exclusão em relação às pessoas que me cercavam.

Estas descrições acima exemplificam as vivências desencadeadas pela manifestação em primeiro plano da estrutura antinômica básica. 
Desta forma, devemos avançar para o argumento seguinte, que nos indicará uma outra desproporção antropológica vivenciada na quarentena. Nosso enfoque sairá da constituição interpessoal da consciência para explorar o impacto na vivência da temporalidade proporcionado pela quarentena.

b) Alterações na temporalidade experimentadas na quarentena: a espera

A perda do Gehäuse pode ser vista também com um enfoque na temporalidade. Para lançar luz às experiências possíveis de serem vividas pela consciência com esse enfoque, utilizaremos conceitos trabalhados por Eugène Minkowski.

Minkowski, um dos psiquiatras pioneiros na utilização de conceitos da fenomenologia para a compreensão dos possíveis modos do adoecimento psíquico, postula em sua obra, influenciado pelo trabalho do filósofo Henri Bergson, a ideia de que a estrutura psíquica, tanto saudável quanto adoecida, assenta-se em um arcabouço têmporo-espacial, e que vivemos o tempo e o espaço de uma forma apriorística, isto é, pré-reflexiva. A partir dos conceitos de devir, inextricável do de tempo: "essa massa fluida, esse oceano em movimento, misterioso, grandioso e potente que vejo diante de mim, em mim, em todas as partes", de que "o reconheço, ao dizer que o tempo flui, que ele passa, que foge de uma maneira inevitável," porém também que "avança, que progride, que vai para um futuro indefinível e inacessível” (Minkowski, 1973, p.22), e de élan vital: “o que dá sentido à vida, constitui (...) o que é mais essencial dela", é a base do que nos permite agir, seja fracassando ou tendo sucesso em nossa ação (1973, p.45), Minkowski defende que a estrutura psíquica saudável "orienta-se essencialmente para o futuro" (1973, p.76). Para Minkowski, "olhamos para o futuro e vemo-lo perder-se ao longe em uma ampla e majestosa perspectiva (...). Faz do futuro algo como uma reserva de forças eterna e inesgotável, sem a qual não poderíamos viver” (1973, p.77).

A partir destas ideias, Minkowski destaca seis fenômenos que constituem os fundamentos do futuro vivido: a atividade e a espera; o desejo e a esperança; a oração e o ato ético. Minuciar cada um dos fenômenos foge do escopo deste artigo. Para a análise da situação atual, destacamos os fenômenos da atividade e da espera, que, de uma maneira dialética, dialogam e se intercalam na estrutura saudável da consciência humana. A partir dessa análise inicial, demonstramos de que forma a experiência da quarentena desproporciona esses fenômenos a favor da espera. 
Minkowski define a atividade como "uma manifestação global do ser vivente, que desconhece a decomposição em uma multiplicidade de ações diferentes, dirigida cada uma para um objetivo preciso; antes bem forma o fundo comum de todas as suas ações, referindo-as umas às outras. É um fenômeno essencial da vida. Tudo o que vive é ativo e tudo o que é ativo vive" (1973, p.79). Assim, Minkowski põe em destaque a ideia de que o fenômeno da atividade se revela no próprio tender e agir em direção a algo; seria a condição de possibilidade para a nossa capacidade de nos dirigirmos ao futuro vivido. A noção de que a atividade é um fenômeno de natureza temporal é o que nos permite avançar em direção ao futuro e criá-lo diante do ser vivente. É também o que nos dá a noção do futuro imediato, futuro este com diversas possibilidades, embora limitadas em quantidade e qualidade pela relação imediata do próprio indivíduo em suas condições de possibilidade ${ }^{12}$ e pelo seu meio, em suas apresentações e significações. É, portanto, a partir de sua relação intencional com o mundo que podemos pensar no ser em atividade, projetando-se para um futuro, com as possibilidades que lhe são dadas.

O autor, assim, propõe que o fenômeno vital que se contrapõe, em dialética, à atividade é a espera; ressaltando que não seria a espera de um evento específico ("um trem que deve passar dentro de meia hora", 1973, p.83), mas que seria algo mais elementar, que "engloba todo o ser vivente, suspende sua atividade e o congela (...) Contém em si um fator de brutal detenção e faz ansioso o indivíduo. Dir-se-ia que todo o devir, concentrado fora do indivíduo, cai, como uma massa potente e hostil, sobre ele, tratando de aniquilá-lo" (1973, p.83). Ao contrário da atividade, em que tendemos para o futuro, na espera, a partir de uma suspensão da própria atividade, o futuro vem a nós.

No atual contexto, a quarentena promoveu alterações radicais na vivência de mundo dos indivíduos. Pensar na pandemia como uma catástrofe é trabalhar com a ideia de que, apesar da realidade estar sempre se transformando, houve, durante essa transformação, uma ruptura de tamanha intensidade que determinou uma nova realidade. Nesta nova realidade, planos realizados são temporariamente suspensos, encontros com amigos e familiares são desmarcados, compromissos são adiados, sem uma previsão de finitude para essa suspensão. De uma forma geral

\footnotetext{
${ }^{12}$ Como coloca Minkowski: "...nem o fracasso nem o êxito modificariam em nada o fenômeno de minha atividade em sua forma primária, não mudariam suas características essenciais, que formam, como acabamos de dizer, a base mesma de nossas experiências relativas ao que somos capazes de fazer e realizar" (1973, p.82).
} 
e global, pode-se dizer que a atividade enquanto fenômeno fica restrita ao futuro imediato e, assim, a espera torna-se o fenômeno preponderante.

Desta forma, passamos a viver o tempo em direção oposta: o futuro vem em direção a nós, ao passo que, na atividade, nós é que nos dirigimos para o futuro. Não há, atualmente, enquanto fenômeno de espera, duração vivida. A organização temporal se dá de forma fragmentada e, de acordo com Minkowski, "Seria falso dizer que na espera vivo o presente e o futuro imediatos unidos; na realidade, somente vivo o futuro, o qual, enquanto tal, tende a converter-se em presente." (1973, p.85). Pode-se dizer que, durante a quarentena, vive-se um desequilíbrio a favor da espera. O futuro, no qual medidas de isolamento não serão mais necessárias, os encontros poderão se dar sem grandes preocupações e as atividades do dia a dia poderão ser novamente retomadas, não está "à mão", é um futuro ao qual não podemos nos dirigir. Encontramo-nos congelados em um presente que não se atualiza, que se relaciona com um futuro que perdeu a sua linha de significação histórica.

Existe, na estrutura da consciência humana saudável, um impulso em renovar-se, e, dessa forma, reconfigurar-se e (re)criar novas possibilidades. Diante do atual entorno, há pouca possibilidade de vislumbre das novas reconfigurações, pois não há um futuro aberto no qual possamo-nos referendar, há a necessidade de esperar as transformações que ainda estão em curso. Como em uma catástrofe, não se pode, a partir do presente, saber de antemão os possíveis desfechos para a atual crise (econômica, social, política) em que vivemos. A impossibilidade atual de "tomar posse" desse futuro pós-pandemia, no sentido de ser ativo na transformação desse próprio futuro a partir de um presente, congela-nos em sucessivos instantes que não se articulam em uma linha temporal fluida.

\section{A quarentena e a perda da evidência natural}

A partir da análise realizada sobre a situação de catástrofe, seguiremos para a discussão do impacto individual na familiaridade com o mundo utilizando o conceito desenvolvido por Wolfgang Blankenburg: a "perda da evidência natural".

A evidência natural seria o piso indistinguível onde a consciência cotidiana habitual se assenta; "(...) constitui o suporte e a base da cotidianidade do ser-no-mundo humano. A ele é próprio então um caráter de fundo e ao mesmo tempo de fundamento." (Blankenburg, 2013, p.153). A experiência de evidência natural acontece a partir da relação do sujeito com o mundo, com a 
temporalidade, com a constituição do "eu" e com a construção intersubjetiva. Na situação analisada neste artigo, descrevemos as alterações provocadas tanto na temporalidade quanto na possibilidade intersubjetiva de compartilhamento de valores estáveis. A pandemia, como um acontecimento histórico que modificou as "regras do jogo", impactou diretamente na possibilidade de reconhecimento tácito das regras compartilhadas da forma de se estar no mundo.

Estas "regras do jogo" ou "generalidades conceituais", vistas de uma perspectiva fenomenológica, não são mais que as relações de respectividade e de referência (Heidegger), dentro das quais se move uma existência (Dasein) em situações que, a rigor e em último termo, apenas constituem uma situação. Elas se baseiam nos significados que determinam o respectivo ser-no-mundo. Não se trata de significados quaisquer, projetados ad hoc, senão de significados historicamente desenvolvidos, nos quais está ancorado o serno-mundo. (2013, p.184)

Para conceituar a evidência natural, Blankenburg utiliza as descrições das experiências de mundo da sua paciente Anna: "Cada pessoa deve saber como se comporta, tem um caminho, uma forma de pensar. Sua atuação, sua humanidade, sua sociabilidade, todas essas regras do jogo que cumpre (...)" (2013, p.109).

Segundo nossa análise, a experiência compartilhada neste momento histórico promoveu uma suspensão neste caminho natural implícito. Significações de vida já não são mais naturais, valores anteriormente tidos como estáveis são modificados.

Essa modificação generalizada pode ser evidenciada, por exemplo, quando passamos a desconfiar de tudo e de todos como potenciais focos de contaminação, determinando que os gestos de aproximação e carinho possam perder seu significado inicial e serem percebidos como gestos ameaçadores, bem como quando passamos a nos questionar sobre determinadas vivências corporais que, anteriormente, seriam ignoradas e, doravante, são sinais de uma doença potencialmente fatal. ${ }^{13}$ Como aponta Naudin,

As relações de distância e de proximidade que compõem o equilíbrio natural das relações intersubjetivas estão profundamente perturbadas e começo a compreender, vivendo intimamente esse desequilíbrio, o quanto a constituição do tempo presente, a qual podemos pomposamente chamar de sua função transcendental, está relacionada àquela da intersubjetividade. Quando não se pode ver o rosto enquanto se fala, nem tocar e ser tocado

\footnotetext{
13 Além da suspensão da forma conhecida de reagir e se relacionar com o mundo, vale ressaltar mais um ponto: o impacto do desconhecido. Trata-se de uma doença nova, com apresentações sintomáticas diversas, sem uma experiência clara compartilhada do que seria essa enfermidade.
} 
pelo outro, o mundo corre o risco de se desencarnar, a própria carne do mundo se desnatura, o tempo se esvazia desmesuradamente. (Naudin, 2020, p.113).

A ancoragem da existência humana se dá a partir dos "axiomas do mundo cotidiano", que "fundamentam o sistema das evidências dentro das quais nos movemos. Eles resgatam o sempre esquecido em sua banalidade. Somente quando desaparecem (...) é que surgem no seu sentido vital que sustenta e garante a normalidade da habitualidade sã." (Blankenburg, 2013, p.161). Para a análise a seguir é importante colocar que a perda da evidência natural, como um momento ou um estado de desenvolvimento da existência, representa um desequilíbrio entre evidência e não evidência, não sendo necessariamente patológico (2013, p.294).

Blankenburg descreve a experiência de "perda da evidência natural" a partir das vivências de sua paciente Ana, descrita como esquizofrênica. Na esquizofrenia, observa-se uma alteração constitutiva da temporalidade, uma desintegração do tempo-vivido (Fuchs, 2013). Destarte, podemos considerar que essa forma de ser-no-mundo "perdeu" a capacidade protentiva e, assim, fica despossada de sua ancoragem no mundo. No caso da experiência relatada neste artigo, em oposição, essa "perda" da evidência é apenas temporária, ainda que prolongada, e os indivíduos têm a possibilidade de um restabelecimento da proporção dinâmica entre evidência e não evidência devido ao caráter protentivo da existência.

\section{Possibilidades de reações psíquicas experimentadas a partir de uma catástrofe}

O desequilíbrio entre evidência e não evidência, suscitado pela situação-limite que vivenciamos neste momento, promove a análise das potências protentivas individuais. Convidado para uma nova experiência de equilíbrio, o indivíduo se abre para o incerto. Determinado pela necessidade de novas configurações estruturais, terá dois caminhos possíveis: (a) a reconstrução de um novo Gehäuse e consequente reconfiguração da dialética entre evidência e não evidência, assim como (b) um estado de desequilíbrio mantido, rompendo com a constituição harmônica da existência - sinônimo de adoecimento psíquico. Para compreender os vetores de reações ontologicamente, é preciso analisar as vulnerabilidades existenciais, a forma com que elas são expostas pela situação-limite. Esses fatores promoverão reconfigurações em cada estrutura individual a ponto de determinar o vetor para o movimento de expansão (ressignificação) ou levar 
à paralisação (o adoecimento). Em uma catástrofe podemos nos recriar, criar uma versão melhor de nós mesmos, assim como podemos sucumbir existencialmente.

Qual é a tragédia necessária para provocar o adoecimento? Em uma definição inicial, poderíamos dizer que um evento traumático diz respeito a qualquer situação que provoque intenso medo, desamparo, horror e que recusa apropriação, simbolização e integração a um contexto significativo (Fuchs, 2013). Desta forma, podemos dizer que se trata de qualquer evento que provoque a vivência de uma iminente fratura estrutural, jogando-nos em uma experiência de pavor. Como coloca López-Ibor: "não importa que a ameaça seja objetivamente certa, basta que ela pareça como tal" (1942, p.56), ou seja, não é um fato isolado em si o ponto de relevância, mas a intensidade da reação e o impacto estrutural que ele desperta individualmente.

Logo, quando tentamos analisar a situação, o olhar se volta obrigatoriamente para a estrutura individual e suas possibilidades de reação frente a uma tensão. Em uma visão estrutural, as características pré-reflexivas constitucionais, em sua relação de intenção com o mundo, determinam os pontos de vulnerabilidade que desenharão as possibilidades de reação, ou seja, uma reestruturação saudável ou uma desconfiguração da estrutura. Cada estrutura é ímpar em relação às suas vulnerabilidades, cada indivíduo ressoará ao movimento de mudança de um modo diferente. Alguns movimentos abalarão o nosso envoltório, deixando-nos vulneráveis a ponto de criar fraturas que levarão ao adoecimento psíquico. O mesmo movimento, em outra estrutura, causará abalos, mas não fraturas. "Tão importante quanto a história externa, o acontecimento traumático, é decifrar a história interna, a vivência."(López-Ibor, 1942, p.103).

Claro que precisamos ressaltar que uma situação catastrófica tem em si uma potência de caos e de imponderabilidade, o que demanda mais das estruturas individuais, com maior risco ao adoecimento. No entanto, o ponto central não é o evento concreto, mas a estrutura biográfica e suas intersecções possíveis com uma situação-limite. Ao conhecer a história de criação individual em uma linha temporal (a biografia) analisamos a totalidade daquela estrutura. Será essa totalidade que norteará o processo psicoterápico, trazendo luz às características pré-reflexivas que promoverão tanto movimento quanto paralisação, ou seja, aquelas que precisam ser potencializadas e aquelas que precisam de cuidados e apoio.

Todo evento assimilado a uma história é impossível de ser retrocedido, pois a biografia é primordialmente apoiada em uma base temporal contínua (Blankenburg, 2018; Tamelini e Messas, 
2019). Algumas situações promoverão relevos mais ou menos determinantes na história, poderão ou não acarretar desvios das trajetórias. Ao trabalhar com as desproporções advindas de um evento catastrófico, estamos avaliando o impacto assim como a capacidade de síntese após um abalo estrutural. Lembrando que é a síntese após uma experiência que permite que a estrutura mantenha seu componente primordial de saúde: a proporção entre as partes (Blankenburg, 1982). Assim, estamos avaliando se o abalo sofrido por essa estrutura é uma paralisação temporária, ou se o impacto seria de tamanha intensidade que poderia acarretar um adoecimento psíquico.

Um exemplo clássico de uma paralisação temporária é o luto. Apesar de todos os comemorativos de afeto desencadeados, o indivíduo mantém um certo controle, uma autonomia psíquica em relação à reação, de forma que coexistem em seu psiquismo as regiões estruturais alteradas pelo luto (por exemplo, intensa tristeza tingindo as atividades do cotidiano) e as saudáveis (manutenção dos projetos individuais ainda que abalados pela perda). Dessa forma, o luto provocará uma paralisação inicial que será gradualmente abandonada a partir da reconfiguração da vivência. Novas experiências trarão novas sínteses aos movimentos psíquicos, possibilitando o desenvolvimento de projetos apesar da perda.

Em uma paralisação temporária, a despeito da intensa angústia, ocorrerá uma reorganização, uma re-harmonização das proporções na estrutura, de forma que a possibilidade de projeção para movimentos de expansão é mantida. Dessa maneira, o psiquismo se restabelecerá com a manutenção da linha de continuidade e o papel do terapeuta será tanto de espectador como de mantenedor das estruturas possíveis que facilitarão o processo de recuperação. Um infinito processo de reorganização psíquica em uma estrutura que tem a protensão como elemento fundamental.

Porém, existe a possibilidade de uma reação que ultrapasse esses limites de saúde. Nas palavras de Jaspers são reações vivenciais cuja intensidade inibe a elaboração ou as reações que trazem consequências obscuras e perturbadoras (Jaspers, 1997). A vida psíquica, nesta situação, encontra um impasse que não é possível de ser transposto e, a partir de então, pelo menos uma parte dessa vida psíquica torna-se imóvel, como um delta de rio que estava se expandindo em leque e que, em determinado momento de sua jornada, perde uma de suas ramificações. O impacto na estrutura como um todo dependerá da importância dessa perda, mas o desenho nunca mais será o mesmo, marcado de forma irrevogável por uma quebra. Uma parte do fluxo originalmente possível 
foi interrompido. Esse seria o conceito de fratura psíquica, de adoecimento. É essa ideia que LópezIbor expressa com maestria em seu texto: "A enfermidade é um acontecer histórico que quebra e perturba o programa vital até um ponto que, na recuperação, se instala um novo projeto na história de vida" (1942, p.104)

A partir da fratura, da remodelação estrutural com perda da proporção prévia entre as partes, a existência é submetida a uma nova forma de experimentar o mundo. Como já definido acima, a evidência de mundo (tal como é reconhecido como familiar) é uma ação intersubjetiva historicamente construída. O psiquismo saudável instala-se sobre uma base dialética ininterrupta entre a experiência de evidência e não evidência. Situações catastróficas, pelos motivos descritos anteriormente, intensificam a tensão dos vetores dessa dialética. Um evento patológico, segundo essa perspectiva, dar-se-ia quando essa relação de tensão é perdida, desconfigurando uma proporção dialética. Isso promoveria a impossibilidade de vivenciar o reconhecimento tácito do mundo, determinando o que Blankenburg chama de "perda da evidência natural" (2013, p.238).

\section{Terapêutica fenomenológica aplicada em momentos de catástrofes}

O valor heurístico do pensamento fenomenológico reside na rica imbricação entre o indivíduo e o mundo encarnado (o mundo experienciado por essa existência). Diferentemente de outras abordagens, que ora pesam excessivamente na historicidade como causalidade, ora pesam na endogeneidade, esse olhar epistemológico é capaz de unir ambas as vertentes em uma visão dialética propícia. Dessa forma, o olhar para a terapêutica avaliará tanto a situação quanto o ser encarnado nessa situação.

Ao reconhecer a patologia como algo que ameaça o fluxo vital e como uma perda da proporcionalidade entre as partes (Minkowski, 1973; Blankenburg, 1982), a terapêutica tem como fundamento ações que promovam a retomada do movimento vital e um reequilíbrio estrutural. As relações de proporção não são estáticas, logo, a proposta de um reequilíbrio das proporções constituintes de uma estrutura é um planejamento que se constrói em uma base temporal (Messas e Tamelini, 2019). A terapêutica fenomenológica oferece tanto uma análise das ações psicoterapêuticas quanto das medicamentosas. As duas modalidades de intervenção apresentam o 
mesmo patamar de importância, desde que prescritas a partir da identificação da essência psicopatológica que se apresenta.

A terapêutica medicamentosa poderia ser proposta tanto em momentos de paralisações temporárias como em fraturas psíquicas na tentativa de promover uma estabilidade, ainda que exógena, que permita o movimento de reconfiguração. A farmacologia não seria analisada como uma via que impossibilitaria ou enfraqueceria o processo psicoterapêutico, mas como uma pavimentação facilitadora do movimento, para o processo de reconfiguração, de reconstrução de cada indivíduo a partir de suas angústias e vulnerabilidades.

Já o processo psicoterápico associado ou não à medicação poderia ser descrito como um acesso ao movimento via interpessoalidade. A interpessoalidade é a possibilidade de comunhão entre duas estruturas pelo contato vital. O espaço que se cria a partir do contato dilata a vivência individual, aumentando a possibilidade de um conteúdo ser amadurecido e assimilado à consciência, acomodando seu impacto inicial e diminuindo fragmentações e distorções. Neste processo, ampliam-se as possibilidades de movimento de um psiquismo abalado pela situação catastrófica. A ancoragem interpessoal promove condições estáveis para o movimento, mesmo em terrenos muito irregulares. Dessa maneira, é a partir de uma nova síntese - uma que, inclusive, carrega em si as cicatrizes dos percalços amargos - que a estrutura pode retomar seus processos de equilíbrio entre as partes.

Para fechar, seria esse o papel de uma terapêutica fenomenológica: como em um teatro grego, permitir que o personagem principal retome a sua história após a catástrofe, reconhecendo suas potências e suas vulnerabilidades, sua essência, potencializando a possibilidade de criação e movimento.

\section{Conclusão}

A pandemia do novo coronavírus causou uma grande alteração no cotidiano das pessoas em diversas sociedades mundo afora. Diante dos diversos dilemas éticos e morais que se apresentaram à sociedade, como a possibilidade de tratamento em UTI's e a incapacidade de assistência a toda a população que dela necessitava, sociedades do mundo inteiro optaram por tentar evitar mortes decorrentes dessa doença por meio do isolamento social. 
Quanto ao processo de quarentena, comparamo-lo a uma catástrofe psíquica, visto que as pessoas foram diretamente afetadas por ele, como nos mostram os diversos artigos que apontam a elevação da taxa de transtornos mentais na população. Tal evento catastrófico foi aqui descrito à semelhança de situações-limite de Karl Jaspers por dois aspectos vivenciais: a subversão de valores e a desproporção da espera em relação à atividade.

A suspensão dos valores que antes figuravam-se como plano de fundo de nossas vidas, associada à vivência de presentificação a partir da inversão temporal, assemelha-se fenomenologicamente à descrição da "perda da evidência natural" em Blankenburg. Conquanto essas experiências possam assemelhar-se em relação a estes aspectos intersubjetivos e temporais, levando, por vezes, à experimentação de perdas de referência em relação ao "eu", a imensa maioria dos indivíduos não perdeu sua constituição protentiva, como no caso da esquizofrenia.

Assim, os indivíduos reconfigurarão suas estruturas individuais a partir das situações em que se inserem e de suas potencialidades individuais a ponto de determinar o vetor para o movimento de expansão (ressignificação) ou levar à paralisação (o adoecimento). Destarte, a terapêutica fenomenológica tem papel fundamental no auxílio a esses sujeitos para que retomem a capacidade de se reorganizarem e superem este momento catastrófico com ainda mais potência e movimento. 


\section{References / Referências Bibliograficas}

Carel, H. (2020). Reflecting on experiences of social distancing. The Lancet, v. 396. https://doi.org/10.1016/.

da Silveira Bueno, F. (1974). Grande dicionário etimológico-prosódico da língua portuguesa. Brasília: Editora Brasília.

EDUCALINGO (2020). Etymonline. $\quad$ Recuperado de https://www.etymonline.com/word/catastrophe.

dos Santos, A. (2005). A tragédia grega: um estudo teórico. Revista Investigações, 18(1), 41-67.

Blankenburg, W. (1982). A dialectical conception of anthropological proportions. Em: de koonig, A.; jenner, F. (Ed.). Phenomenology and Psychiatry. London, Toronto and Sydney: Academic Press, p.35- 50.

Blankenburg, W. (2018). Qual é o alcance da abordagem dialética na psiquiatria? Revista Psicopatologia Fenomenológica Contemporânea, 7(1), 44-67.

Blankenburg, W. (2013). La pérdida de la evidencia natural: Una contribución a la psicopatología de la esquizofrenia. Universidad Diego Portales.

Fuchs, T. (2013). Existential vulnerability: toward a psychopathology of limit situations. Psychopathology, 46(5), 301-308.

Giorgio Agamben (2020), "Biosicurezza e politica", Quodlibet. Recuperado de https://www.quodlibet.it/giorgio-agamben-biosicurezza.

Jaspers, K., \& Casero, M. M. (1967). Psicología de las concepciones del mundo. Madrid: Gredos.

Jaspers, K. (1997). General psychopathology (Vol. 1). JHU Press.

López-Ibor, J. J. Neurosis de guerra (psicología de guerra). Editorial Científico Médica (Barcelona, Madrid) 1942, 177p.

Luo, M., Guo, L., Yu, M., \& Wang, H. (2020). The Psychological and Mental Impact of Coronavirus Disease 2019 (COVID-19) on Medical Staff and General Public-A Systematic Review and Meta-analysis. Psychiatry Research, 113190.

McGinty, E. E., Presskreischer, R., Han, H., \& Barry, C. L. (2020). Psychological Distress and Loneliness Reported by US Adults in 2018 and April 2020. JAMA. 
Messas, G. (2012). A noção de estrutura na psicopatologia/psicologia fenomenológica. Uma perspectiva epistemológica. A. Rodrigues, L. Streb, M. Daker, \& O. Serpa, Psicopatologia Conceitual, 51-62.

Messas, G., \& Tamelini, M. (2019). The pragmatic value of notions of dialectics and essence in phenomenological psychiatry and psychopathology. Thaumàzein| Rivista di Filosofia, 6, 93-115.

Minkowski, E. (2019). Lived time: Phenomenological and psychopathological studies. Northwestern University Press.

Naudin, J. (2020). Opinião dos Especialistas - O mundo e a Covid-19. Revista Psicopatologia Fenomenológica Contemporânea, 9(1), 108-116.

Tamelini M. G., Messas, G. P. (2019) Pharmacological Treatment of Schizophrenia in Light of Phenomenology. Philosophy, Psychiatry, \& Psychology, 26(2), 133-142.

Shi, L., Lu, Z.-A., Que, J.-Y., Huang, X.-L., Liu, L., Ran, M.-S., ... Sun, Y.-K. (2020). Prevalence of and risk factors associated with mental health symptoms among the general population in China during the coronavirus disease 2019 pandemic. JAMA network open, 3(7), e2014053e2014053.

Wang, C., Pan, R., Wan, X., Tan, Y., Xu, L., McIntyre, R. S., . . . Sharma, V. K. (2020). A longitudinal study on the mental health of general population during the COVID-19 epidemic in China. Brain, behavior, and immunity. 